\title{
Nasionalisme Qurani dan Relevansinya dengan Semangat Kebangsaan Indonesia: Studi QS. [49]: 13, QS. [89]: 8 dan QS. [2]: 143
}

\author{
Lufaefi ${ }^{a, 1, *}$ \\ ${ }^{a}$ Institut Perguruan Tinggi Ilmu Al-Quran (PTIQ) Jakarta 10110, Indonesia \\ eepivanosky@gmail.com
}

ARTICLE INFO ABSTRACT

Article history:

Received : 2019-02-08

Revised : 2019-04-08

Accepted : 2019-05-22

Keywords:

Quranic Nationalism

Nationalism

Xenophobia

Kata Kunci:

Nasionalisme Qurani

Nasionalisme

Xenophobia
In the modern era, it emerges a movement wanting to reject the concept of nationalism and replace it with the idea of islamic khilafah, since nationalism only makes humans become worse. The spirit of life is based solely on competition of hatred and evil (xenophobia). This is caused by reality, since the growing nationalism is not based on the Qur'an, but it only inherits the West. With textual and contextual analysis of the verses of nationalism, this paper presented nationalism in the perspective of Qur'an through verses about the state and nation. This paper wants to examine how nationalism is desired by Qur'an and how relevant it is to the nationalism of Indonesian people. The result, the nationalism desired by Qur'an is a spirit of nationality, not nationalism based on pride. Quranic nationalism makes the nation compete with other nations in the world in achieving common goals. This is relevant to the spirit of Indonesian nationalism, at least there are three principles matching it, namely unity, justice and prosperity.

\section{ABSTRAK}

Di era modern sekarang, muncul gerakan yang ingin menolak konsep nasionalisme dan menggantinya dengan gagasan khilāfah islāmiyyah. Dengan alasan karena nasionalisme hanya membuat manusia menjadi lebih buruk. Semangat hidup hanya didasarkan pada kompetisi yang sarat akan kebencian dan kejahatan (xenophobia). Hal demikian disebabkan oleh kenyataan karena nasionalisme yang tumbuh saat ini tidak didasarkan pada al-Quran, namun hanya mewarisi Barat. Dengan analisis tekstual dan kontekstual terhadap ayat-ayat nasionalisme, tulisan ini mengungkap nasionalisme dalam perspektif al-Quran melalui ayat-ayat tentang negara dan bangsa. Dengan makalah ini ingin menelaah bagaimana nasionalisme yang diinginkan oleh al-Quran dan seberapa relevan dengan nasionalisme bangsa Indonesia. Hasilnya, nasionalisme yang diinginkan al-Quran adalah semangat kebangsaan, bukan nasionalisme yang didasari kesombongan. Nasionalisme alQuran membuat bangsa bersaing dengan bangsa-bangsa lain di dunia dalam mencapai cita-cita bersama. Ini relevan dengan semangat kebangsaan bangsa Idonesia, setidaknya terdapat tiga prinsip yang menyamainya, yaitu persatuan, keadilan dan kesejahteraan.

\section{Pendahuluan}

Tidak bisa diingkari bahwa setiap manusia memiliki semangat mencintai tempat di mana mereka tumbuh di dalamnya. Manusia menginginkan tempat kelahirannya menjadi tempatnya menua dan menghabiskan masa hidupnya.(7) Hal ini yang kemudian DOI:10.23971/jsam.v15i1.1172 memikat manusia untuk mencintai negaranya setengah mati.(28) Setiap manusia juga memiliki cita-cita luhur untuk berprestasi demi bangsanya sendiri. Demikian itu bisa dibuktikan dengan solidaritas setiap bangsa dalam mengorbankan harta benda, tenaga dan fikirannya dalam rangka memajukan

W : http://e-journal.iain-palangkaraya.ac.id/index.php/jsam E : Jsam.iainpky@gmail.com 
bangsanya agar mampu bersaing dengan bangsa-bangsa yang lainnya. Selain itu, satu sama lain diantara anak bangsa juga memiliki keinginan kuat untuk bersama-sama membangun kemajuan bangsanya, baik dalam bidang ekonomi, keamanan bangsa, ataupun kemajuan dalam bidang pendidikan.(34) Semua itu dilakukan tidak lain karena kecintaan mereka kepada tanah Air yang telah menjadi tempatnya tumbuh besar.

Grosby mengungkapkan bahwa kecintaan seseorang terhadap bangsanya sendiri akan menumbuhkan kreativitas yang berkualitas baik bagi individu-individu yang ada di dalam bangsa itu sendiri atau untuk kepentingan kolektif selain kelompoknya.(15) Hal yang sama juga ditegaskan oleh Muhammad Luṭī As-Șibāghī, bahwa menurutnya, dengan semangat kecintaan seseorang terhadap bangsa dan negerinya, seseorang akan berjuang dan mengangkat martabat bangsanya.(40) Sehingga dengan demikian, setiap manusia memiliki dorongan yang kuat untuk hidup lebih baik bagi dirinya, bangsanya, bahkan untuk dunia. Selain itu, mereka memiliki visi kehidupan yang jelas di masa depan yang akan datang untuk menjadi manusia yang berguna bagi nusa dan bangsanya.(18)

Istilah sosial politik, sikap cinta kepada tanah Air dan bangsa yang diwujudkan dengan perjuangan demi kemajuan aspekaspek positifnya ini disebut dengan Nasionalisme.(6) Nasionalisme juga dijabarkan dengan maksud sebuah sikap yang dimiliki seseorang yang hidup dalam sebuah bangsa yang menginginkan bangsa dan negerinya sendiri lebih sejahtera dan lebih maju dibandingkan dengan bangsa dan negeri lain. Hal itu berbeda dengan panislamisme, yaitu sebuah faham yang memperjuangkan persatuan, kesejahteraan dan kemajuan bagi seluruh umat se-dunia, khususnya Islam, tanpa dibatasi oleh wilayah-wilayah tertentu sebagaimana bentuk negara-bangsa dalam konsep nasionalisme.(8)

Namun meskipun nasionalisme menjadi hal penting bagi setiap individu manusia untuk memajukan bangsa dan negaranya, faham tersebut masih banyak yang menentangnya. Menurut Bawazir, konsep ini ditentang setidaknya karena dua alasan. Pertama, konsep nasionalisme dianggap berlawanan dengan konsep persatuan dalam agama Islam yang mengajarkan persatuan umat manusia tanpa dibatasi oleh teritorial wilayah-wilayah tertentu. Alasan kedua, karena dalam tataran historisnya, nasionalisme tumbuh dari Barat (diidentikkan sebagai produk kafir), sehingga dianggap tidak layak untuk digunakan oleh negaranegara berpenduduk mayoritas muslim.(12) Hal ini yang barangkali memunculkan sebagian kelompok Islam yang menolak konsep nasionalisme di berbagai belahan dunia, tidak terkecuali di Indonesia sebagai negara yang mayoritas penduduknya muslim.

Atas tesis di atas, dikatakan bahwa Islam dan nasionalisme merupakan dua hal yang bertentangan secara subtansif. Dimana Islam mengajarkan nilai-nilai persatuan yang universal tanpa pembatasan wilayah-wilayah tertentu, sementara nasionalisme hanya mengajarkan nilai-nilai persatuan yang partikular yang diklaim hanya akan memecah belah umat Islam di dunia dan persoalan inilah yang kemudian menimbulkan reaksi pro dan kontra diantara para tokoh dan ulama dunia.(25)

Menurut Abdullah, dalam konteks keindonesiaan, penolakan terhadap nasionalisme ini pada gilirannya menjadikan wawasan kebangsaan sebagian orang cenderung melemah, alasan yang mewarnai tumbuhnya asumsi-asumsi terlarangnya nasionalisme adalah karena pemahaman terhadap agama yang cenderung formalistik, sempit dan ekslusif.(21)

Namun kemudian, persoalan penolakan nasionalisme dengan argumen bahwa nasionalisme akan memecah belah umat ini dibantah oleh Bawazir. Dalam karyanya menyatakan bahwa dengan nasionalisme tidak berarti hendak memecah belah umat Islam. Menurutnya melalui konsep nasionalisme satu sama lain antar bangsa dapat berlomba-lomba dalam kebaikan, sebagaimana itu merupakan salah satu misi Islam dan Al-Quran.(12) Hal ini juga didukung oleh Iqbal, Cendekiawan Pakistan kontemporer, yang menyatakan bahwa nasionalisme tidak akan memecah belah persatuan umat Islam. Menurutnya, perbedaan teritorial tidak berarti akan berdampak pada perpecahan. Bahkan, AlQuran sendiri pun mengajarkan perbedaan, 
sekaligus menuntut umat Islam untuk berlomba-lomba dalam kebaikan.(20)

Tetapi cukup disayangkan, Bawazir dan Iqbal tidak menyebutkan secara rinci, tegas dan jelas bagaimana nasionalisme yang cocok digunakan (khususnya bagi negara mayoritas muslim) sebagaimana yang dimaksud. Keduanya hanya memberikan argumen bahwa nasionalisme sesungguhnya tidak akan memecah belah umat Islam. Hal inilah yang barangkali memberi dampak terhadap model nasionalisme yang ada di sebagian besar negara dunia tidak terkecuali negara mayoritas muslim yang hingga saat ini nasionalismenya bermakna sempit, yaitu nasionalisme yang menganggap rendah bangsa-bangsa lain (chauvinistic), bahkan berambisi menjajahnya.(17)

Hal di atas dipertegas oleh pernyataan Alan bahwa nasionalisme yang berkembang di dunia pada saat ini memiliki dua hal negatif, yaitu xenophobia dan chauvinisme. Xenophobia yaitu kecenderungan sebuah bangsa menganggap rendah kebudayaan bangsa lain. Sedangkan chauvinisme ialah faham yang mengagungkan bangsanya sendiri dan menganggap rendah bangsa-bangsa lain.(3) Dalam tataran praktis, bentuk nasionalisme demikian telah terjadi pada perang Dunia II yang dipicu oleh negaranegara blok Axis, seperti Jerman yang mengagungkan bangsa Arya, Italia dengan faham Fasisme, dan Jepang dengan semangat Hakko Ichiu dalam rangka mendirikan Asia Timur Raya.(17) Nasionalisme demikian memandang bahwa hanya bangsa sendirilah yang berhak sejahtera, sedangkan bangsa lain boleh tertindas dan bahkan boleh dijajah.(40) Nasionalisme model demikian pada gilirannya hanya menjadikan kebencian sebagai dasar kebangsaannya. Sebaliknya, tidak memiliki visi untuk membangun bangsa yang bermartabat di mata dunia.

Grosby dalam karyanya menyatakan bahwa semua nasionalisme yang tumbuh di dunia pada saat ini bersifat chauvinisme dan xenophobia, sebab menurutnya bangsa mana saja dipastikan memiliki keinginan untuk unggul dan menguasai bangsa-bangsa lain.(15)

Sementara itu, klaim bahwa nasionalisme hanya akan memecah belah umat Islam ialah sebagaimana sebuah penelitian yang dilakukan oleh Dian dengan menyatakan bahwa masih banyak kelompok Islam yang menentang konsep nasionalisme dan memperjuangkan konsep persatuan umat seluruh dunia dengan sistem khilāfah islāmiyyah sebab menganggapnya telah menghancurkan umat Islam sejak masa runtuhnya khalifah Turki Usmani hingga masa modern saat ini, seperti HTI dan Ikhwanul Muslimin.(13)

Sampai disinilah bahwa konsep nasionalisme dihimpit dua persoalan besar. Dalam satu sisi nasionalisme masih ditentang oleh sebagian umat Islam dengan klaim akan memecah belah umat muslim, dan disisi lain nasionalisme yang berkembang pada saat ini justru cenderung bersifat xenophobia dan chauvinisme, yakni mengangap remeh bangsa-bangsa lain, bahkan memiliki ambisi untuk menjajahnya.(15)

Kenyataan di atas sudah seharusnya menjadi inspirasi, motivasi dan koreksi bagi orang Islam, khususnya bagi para pengkaji AlQuran untuk menemukan konsep nasionalisme berbasis Qur'ani sebagai jawaban atas problematika di atas. Sebagaimana diyakini bahwa Al-Quran adalah wahyu yang menjelaskan segala permasalahan apapun baik secara tersurat ataupun tersirat, kapanpun dan di manapun. Terlebih, ketika negara-negara yang dihuni penduduk muslim termasuk di Indonesia telah banyak menganut nasionalisme. Maka, menemukan konsep nasonalisme qur'ani bagi seorang muslim adalah suatu keharusan.

\section{Tinjauan Pustaka}

\section{a. Nasionalisme dan Pro-Kontranya}

Secara etimologi, kata nasionalisme diambil dari bahasa Inggris; nation, yang memiliki arti bangsa, dan isme yang bermakna paham. Ketika keduanya disatukan, menjadi "nasionalisme", yang memiliki makna paham mencintai bangsa atau tanah air.(25) Berbeda dengan pengertian etimologi di atas ialah pengertian yang didefinisikan oleh Kohn. Pakar sejarah asal Eropa ini menyatakan bahwa term nasionalisme, natie dan national, kesemuanya berasal dari bahasa Latin, yakni natio, yang berarti bangsa yang dipersatukan 
karena kelahiran. Kata natio ini berasal dari kata nascie yang memiliki arti dilahirkan.(23) Kohn juga mendefinisikan kata nasionalisme secara terminologi, yaitu suatu paham yang mengajarkan bahwa kesetiaan tertinggi individu harus diserahkan kepada bangsa. Menurutnya, pengertian ini berlaku untuk bangsa yang pernah dijajah ataupun tidak. Sedangkan Stoddard, sebagaimana dikutip oleh Yatim, juga memaknai nasionalisme secara terminologi, yaitu keadaan jiwa dan kepercayaan yang dianut oleh sejumlah manusia sehingga membentuk kebangsaan. Menururtnya, nasionalisme merupakan rasa kebangsaan yang manusiawi sebagai wujud sebuah bangsa.(39)

Nasionalisme sendiri tumbuh di negaranegara dunia dengan latar belakang yang berbeda-beda. Dimana dari sisi teritorial, kemunculan nasionalisme berasal dari wilayah Barat dan kemudian menyebar ke dunia bagian Timur. Dalam perkembangannya itu, faham ini mengalami pro-kontra di antara para pakar. Al-Maududī misalnya, adalah salah satu tokoh yang menolak ide nasionalisme. Sejak runtuhnya kekuasaan Turki Usmani, dirinya banyak berubah, dan hal yang paling menonjol ialah tentang penolakannya terhadap ide nasionalisme yang pada saat itu diyakini oleh negara-negara Islam, seperti Turki dan Mesir. Baginya, nasionalisme hanya akan memecah belah persatuan umat Islam sebab mereka dipisahkan oleh teritorial-teritorial wilayah tertentu.(36)

Selanjutnya adalah Sayyid Qutb, satu tokoh Islam yang juga menolak ide nasionalisme. Menurutnya, pemerintahan yang didasari faham nasionalisme tidak lain telah gagal. Hal tersebut karena telah meniru Barat (kufur) yang mencoba memisahkan antara agama dengan masyarakat, atau masyhur dikenal dengan Sekularisme. Padahal menurutnya, sistem Barat dengan berpacu pada agama Kristen, tidaklah memberikan perundang-undangan yang memadai untuk mengatur kehidupan seharisehari mereka. Oleh sebab itu dirinya menolak nasionalisme dan tetap mengajukan negara Islam yang baginya diyakini akan menjamin pembagian kekayaan secara merata, dan memberikan bimbingan dalam kebijakankebijakan umum. Oleh sebab itu, menurutnya
Islam harus menjadi ideologi umat manusia.(33)

Sementara itu, Azyumardi Azra, Cendikiawan Muslim Indonesia, mendukung nasionalisme. Guru Besar UIN Syarif Hidayatullah Jakarta ini menyatakan, bahwa tidak ada alasan untuk menerima nasionalisme untuk disinergikan dengan agama Islam. Karena menurutnya, integrasi Islam dan Nasionalisme bukanlah sesuatu yang mati dan sudah berakhir (taken for granted). Baginya, kedua hal tersebut akan terus berkembang sesuai perkembangan manusia ke depan, sehingga nilai-nilai Islam berkesempatan besar untuk menyatu dengan nasionalisme. Tidak ada pertentangkan antara Islam dan nasionalisme, walaupun disadari bahwa nasionalisme memang tumbuh dari Barat.(11)

\section{b. Nasionalisme dalam Lintas Sejarah}

Nasionalisme tumbuh di negara-negara dunia dengan latar belakang yang berbedabeda. Dimana dari sisi teritorial, kemunculan nasionalisme bermula dari wilayah Barat dan kemudian meluas ke dunia bagian Timur. Oleh alasan tersebut, di bawah ini akan dijelaskan secara global latar belakang munculnya nasionalisme baik di wilayah Barat atau Timur, dan termasuk di negaranegara Asia, tidak terkecuali nasionalisme di Indonesia.

\section{Nasionalisme di Barat}

Nasionalisme di Barat lahir sejak abad XIV. Timbulnya nasionalisme di dunia Barat bermula terjadi di negara-negara Eropa, seperti Inggris, Prancis, Jerman dan Italia. Menurut Surya, nasionalisme yang tumbuh di Barat secara umum bersifat xenophobia, yaitu nasionalisme yang lahir dan berkembang dalam rangka membanggakan negaranya sendiri, dan menganggap bangsa lain sebagai bangsa yang lemah. Selain itu berlandaskan atas perlawanan kepada para penguasa dan atau sistemnya yang dianggapnya hanya menyengsarakan rakyat.(38)

\section{Nasionalisme di Timur}

Adapun nasionalisme di negara bagian Timur munculnya dilatarbelakangi oleh hal yang berbeda dengan nasionalisme di dunia Barat. Jika nasionalisme di Barat muncul sebab melawan kediktatoran kekuasaan atau 
sistem yang menindas suatu bangsa, maka nasionalisme di Timur termasuk di Asia Tenggara muncul sebab reaksi terhadap kolonialisme, imperalisme dan atau latar belakang nenek moyang tertentu. Nasionalisme di dunia Timur ini merupakan fenomena yang mulai berkembang di abad 20.(26) Negara-negara di dunia Timur penganut nasionalisme, yaitu di Jepang, Vietnam, Birma, Malasyia, Singapura, Filipina, Thailand, Tiongkok, India dan Indonesia. Secara umum, landasan tumbuhnya nasionalisme di dunia Timur berbeda-beda, ada yang berasaskan xenophobia, warisan nenek moyang, dan ada juga yang tumbuh karena semangat kebangsaan melawan penjajahan.(25) Hal itu berbeda dengan penelitian Wawan, yang menyimpulkan bahwa nasionalisme di manapun tidak bisa lepas dari sifat chauvinistic dan xenophobia, yang memiliki keinginan untuk menjelekkan bangsa di luar bangsanya, bahkan menjajahnya.(3)

\section{Nasionalisme Indonesia}

Secara historis, nasionalisme di Indonesia sudah lahir sejak berdirinya organisasi Budi Utomo pada tanggal 20 Mei 1908. Pada mulanya, Budi Utomo merupakan organisasi yang berasaskan hubungan spiritual dan kepentingan perdagangan. Namun kemudian menjadi gerakan nasionalisme masyarakat Indonesia.(29)

Setelah Budi Utomo kemudian lahirlah Sarekat Islam (SI) pada tahun 1912. Sarekat Islam mengalami kemajuan yang sangat cepat dibandingkan Budi Utomo. Akan tetapi karena keterbukaannya, organisasi ini terpecah menjadi dua, yaitu SI Putih dan SI merah. Perbedaannya, jika SI Putih masih menjadikan Islam dan Pan-Islamisme sebagai landasan untuk persatuan, sedangkan SI Merah yang pada selanjutnya melahirkan Partai Komunis Indonesia (PKI) yang berpegang teguh pada sosialisme, internasionalisme, dan menolak nasionalisme.(1) Pada gilirannya, PKI semakin membesar, dan besarnya partai PKI inilah yang kemudian melakukan pemberontakan kepada pemerintah Belanda pada tahun 13 November 1926, dan menyebabkan banyak tokoh pergerakan nasional diasingkan ke daerah-daerah terpencil.(25)
Pada kelanjutannya, PKI dinyatakan sebagai partai terlarang oleh pemerintah Belanda. Atas hal ini kemudian Soekarno memiliki inisiatif agar bangsa Indonesia memiliki partai sendiri sebagai penggerak nasionalisme modern. Akhirnya pada tanggal 4 Juli 1927 lahirlah Partai Nasional Indonesia (PNI) yang memiliki ideologi nasionalisme radikal. Bukan hanya itu, selain nasionalisme radikal, ide yang dipakai dalam partai tersebut adalah islamisme dan marxisme. Ketiga konsep ini dikenal dengan NASAKOM. Pada 25 Desember 1912 lahir pula partai yang berjiwa nasionalisme modern, yaitu Indiche Partij yang didirikan oleh E.F.E. Douwes Dekker, seorang Indonesia yang memiliki keturunan Belanda. Akan tetapi partai ini tidak banyak direspon oleh pemerintah.(25)

Setelah itu, lahir pula Organisasi Islam Muhammadiyah di Yogyakarta pada 18 November 1912 dengan semangat pendidikan yang berdasarkan keagamaan. Kemudian pada 31 Januari 1926 lahir pula organisasi masyarakat Nahdlatul Ulama yang mengedepankan semangat nasionalisme Indonesia, dan juga dikenal sebagai responden terhadap kelompok Serikat Islam dan Muhammadiyah yang tidak mengirimkan delegasi bangsa Indonesia di Kongres Umat Islam dunia di Kairo.(10)

Selain lahir nasionalisme dari orangorang Islam, lahir pula rasa cinta kebangsaan dari kelompok Katolik Indiche Katholieke Partji (IKP) pada November 1918; Christelijke Ethische pada September 1917; dan Nasrani Partai Katolik Djawi pada 22 Februari 1925. Selain itu, lahir juga partaiparta kedaerahan yang juga membawa semangat kebangsaan, seperti Pasundan, Serikat Sumatra, Perkumpulan Orang-orang Ambon, Minahasa, Perkumpulan Betawi, Jong Java, Jong Sumatranen Bond, Jong Minahasa, Jong Ambon, Jong Celebes, Jong Islamieten, dan Perhimpunan Indonesia pada 1922 di Belanda.(1)

Nasionalisme Indonesia mendekati konkrit setelah Pemerintah membentuk BPUPKI pada 1 Maret 1945. Dalam sidang tersebut para tokoh mengajukan dasar negara yang cocok bagi bangsa Indonesia. Mr. Muhammad Yamin, mengajukan bahwa dasar negara ialah: peri kebangsaan, kemanusiaan, ketuhanan, kerakyatan dan kesejahteraan 
masyarakat. Setelah itu Soepomo mengajukan dasar negara dengan integralitas antar seluruh warga Indonesia tanpa dibedakan dengan apapun. Dan akhirnya pada 1 Juni 1945, Soekarno mengajukan pandangan dasar negara dengan Pancasila, yang meliputi kebangsaan, internasionalisme, mufakat, kesejahteraan dan ketuhanan.(16)

Sebelum memasuki persidangan kedua, dibentuk panitia sembilan untuk kemudian merumuskan hal-hal yang akan dibicarakan pada tanggal 10 Juli 1945. Setelah itu disepakatilah kesepakatan antar pihak kebangsaan dan pihak Islam. Persetujuan itu termaktub dalam satu rancangan hukum dasar. Selain itu juga merumuskan dasar negara Indonesia yang berbunyi; ketuhanan dengan kewajiban menjalankan syariat Islam bagi pemeluk-pemeluknya; menurut dasar kemanusiaan yang adil dan beradab; persatuan Indonesia; dan kerakyatan yang dipimpin oleh hikmat kebijaksanaan dalam permusyawaratan perwakilan; serta dengan mewujudkan suatu keadilan sosial bagi seluruh rakyat Indonesia.(25) Rumusan negara ini disepakati pada 22 Juni 1945 dengan nama Jakarta Charter atau Piagam Jakarta.

Pada sidang ke dua, terjadi perdebatan sengit menyangkut dua kalimat yang krusial, yaitu redaksi dengan kewajiban menjalankan syariat Islam bagi pemeluk-pemeluknya, dan orang Indonesia asli dan beragama Islam bagi seorang presiden, sebagaimana termuat dalam salau satu pasal UUD. Dari dua kalimat tersebut di atas, yang pertama telah disepakati untuk dijadikan sebagai Piagam Jakarta, atau lebih tepatnya sebagai Mukaddimah UUD 1945. Namun, kalimat kedua tidak disepakati dan akhirnya dihapus. Pada sidang PPKI 18 Agustus 1945, konsep Mukaddimah UUD 1945 yang disahkan adalah yang dirumuskan oleh Panitia Sembilan, yaitu kewajiban menjalankan syariat Islam bagi pemelukpemeluknya. Akan tetapi sebelum disahkan atas prakarsa Hatta setelah mendapat pesan dari tokoh-tokoh Kristen sila pertama tersebut dirubah menjadi Ketuhanan yang Maha Esa. Rumusan tersebut disepakati setelah Hatta pasca berkonsultasi dengan empat tokoh Islam, yaitu Kiai Bagus Hadikusumo, Kiai Wahid Hasyim, Kasman Singodimejo dan Teuku Moh. Hassan.(16)
Ketika Indonesia diproklamirkan pada tanggal 17 Agustus 1945 sebagai negara bangsa, hal tersebut menjadi prinsip hidup bernegara yang sangat tepat dan fundamental, yaitu negara kesatuan yang demokratis.(31) Dari sini, jika kita telaah lebih mendalam, lahirnya nasionalisme Indonesia disebabkan karena semangat melawan penjajahan secara seksama, walaupun di dalamnya terdapat berbagai kelompok, partai, agama, dan budaya, namun bangsa Indonesia dapat mempertahankan kebangsaannya demi terbebas dari kungkungan penjajah.

Nasionalisme para pejuang di atas diawali dengan perjuangan mencerdaskan rakyat Indonesia, kemudian mengupayakan gerakangerakan perlawanan terhadap ketidakadilan para kolonial pemerintahan Hindia-Belanda pada rakyat Indonesia.(22) Dari rentetan sejarah tersebut dipahami pula bahwa konstruksi nasionalisme Indonesia bukan untuk melahirkan masyarakat yang politis atau masyarakat yang ekonomis. Akan tetapi demi terciptanya masyarakat yang manusiawi dalam payung perbedaan untuk mencapai citacita bersama, yang walaupun di dalamnya banyak terdapat keberagaman, tetapi tetap satu dalam satu kesatuan NKRI.

\section{c. Problematika Nasionalisme}

Seiring dengan berjalannya waktu dan dengan perkembangan kehidupan peradaban manusia, nasionalisme terus mendapatkan tantangan yang mencoba menggerus eksitensinya. Dalam sub bab ini akan dipaparkan problem-problem yang dihadapi sebuah bangsa dalam mempertahankan nasionalismenya. Problema di bawah merupakan hasil konstruksi penulis dari masalah-masalah yang condong dalam nasionalisme Indonesia, meskipun tidak menutup kemungkinan juga menjadi problem bagi nasionalisme-nasionalisme di dunia luar.

Pertama, sentimen keagamaan; faktor ini merupakan faktor yang biasanya muncul di negara-bangsa yang mayoritas berpenduduk muslim, seperti Indonesia. Sentimen keagamaan di sini ialah berupa ajaran dan paham trans-nasional dengan menuduh nasionalisme sebagai paham sekuler dari Barat yang tentunya tidak boleh dianut oleh warga muslim. Dengan mengusung visi "khilāfah islāmiyyah", kelompok-kelompok 
keagamaan ini menolak nasionalisme.(12)

Kelompok-kelompok ini seperti Hizbut Tahrīr, Front Pembela Islam (FPI) dan Ikhwān al-Muslimīn.

Kedua, lemahnya semangat nasionalisme dan lunturnya identitas bangsa yang mengcaman terhadap kesatuan bangsa.(32) Masalah kedua inilah yang, hemat penulis, kemudian berimplikasi kepada rendahnya semangat anak bangsa untuk berbakti kepada negerinya. Lemahnya semangat nasionalisme juga menjadikan lemahnya cita-cita individu bangsa untuk menjadikan bangsa Indonesia sebagai bangsa yang mampu bersaing dengan bangsa-bangsa lainnya. Problem kedua ini betapapun sangat membahayakan jika terus dibiarkan.

Ketiga, fanatisme negatif; problem ini muncul hampir di sebagian besar nasionalisme di dunia. Fanatisme negatif ialah buah dari nasionalisme yang bermakna sempit, yaitu mengunggulkan bangsanya sendiri dan merendahkan bangsa-bangsa lain. Sikap demikian secara tidak langsung bukan memaksimalkan peran nasionalisme yang seharusnya merangkul semua perbedaan dan keragaman, tetapi justru akan memicu pertumpahan antar bangsa baik di internal atau eksternal bangsa, yang pada akhirnya akan berdampak kepada eksistensialisme nasionalisme dalam sebuah bangsa.(19)

Keempat, kedaulatan negara; kedaulatan adalah suatu hak ekslusif untuk menguasai suatu wilayah negara, pemerintahan, masyarakat atau bangsanya. Namun masih banyak kedaulatan bangsa Indonesia yang masih dikuasai atau tidak menjadi bahan kerjasama antar warga asing. Misalnya, dalam kasus Indonesia, dalam hal minyak, perusahaan asing menguasai $67 \%$. Atau dari sisi migas, 120 blok dikuasai asing dan 77 blok lainnya kerjasama antar asing dan perusahaan Indonesia. Begitu juga perusahaan-perusahaan lain seperti Freeport dan Newton Nusa tenggara.(30)

Kelima, keadilan sosial; problem keadilan sosial merupakan masalah yang cukup pelik dalam negara nasionalisme. Dalam konteks keindonesiaan, masih banyak keadilan sosial yang belum merata. Misalnya, perbaikan sumber daya alam akan tetapi bersamaan itu merusak lingkungan di sejumlah kawasan; penggundulan hutan dilakukan untuk membangun Villa para pejabat atau pengusaha; dan penggalian bahan tambang di kawasan konservasi. Semua itu mengakibatkan kebanjiran di daerah-daerah miskin yang bertempat tinggal di bantaran sungai, dan kemiskinan merajalela akibat semua itu.(14)

Problem-problem nasionalisme di atas merupakan tantangan bagi sebuah bangsa untuk mempertahankan nasionalismenya. Perkembangan zaman pasti akan melunturkan nasionalisme dalam sebuah negara. Melalui penelitian ini, penulis ingin menelaah bagaimana nasionalisme dalam Al-Quran dan prinsip-prinsip yang ada di dalamnya, untuk kemudian mendapatkan konsep nasionalisme berbasis Al-Quran yang sālih likulli zamān wal makān dan dapat menjadi inspirasi dalam praktik bernasionalisme di Indonesia dan untuk dunia.

\section{d. Ayat-Ayat Al-Quran Tentang Nasionalisme}

Istilah nasionalisme secara eksplisit tidak termaktub di dalam mushaf Al-Quran. Quraish Shihab mengatakan bahwa paham tersebut belum dikenal pada masa turunnya Al-Quran. Paham tersebut baru muncul pada abad ke-18 dan setelah itu menyebar ke seluruh dunia, termasuk di negara-negara yang mayoritas berpenduduk muslim, termasuk di Indonesia.(35) Hemat penulis, alasan inilah yang menjadikan terma nasionalisme tidak disebutkan secara jelas dan tersurat di dalam mushaf Al-Quran.

Namun walaupun secara tertulis istilah nasionalisme tidak terdapat di dalam AlQuran, bukan berarti konsep tersebut tidak ada sama sekali di dalam wahyu ilahi tersebut. Karena Al-Quran diyakini menjelaskan segala persoalan yang ada di muka bumi, bahkan di akhirat sekalipun. Al-Quran tidak sedikitpun luput dalam membahas persoalan apapun (tibyānan likulli syai'in), tidak terkecuali persoalan nasionalisme.

Mustaqim mengatakan bahwa, untuk menemukan konsep yang secara tersurat tidak termaktub dalam Al-Quran caranya ialah dengan menganalisa dan menggali subtansisubtansi ayat Al-Quran yang memiliki nilainilai yang sama dengan nilai-nilai yang dimiliki oleh konsep yang akan diteliti,(27) dalam penelitian ini adalah nilai-nilai 
nasionalisme. Dalam sub bab sebelumnya dijelaskan bahwa nasionalisme ialah paham mencintai bangsa dan negara.(37) Maka, hemat penulis, untuk menemukan konsep nasionalisme adalah dengan melihat ayat-ayat Al-Quran yang berbicara tentang sikap kecintaan seseorang terhadap negeri atau bangsanya sendiri.

Atas dasar di atas, dalam penelitian yang bertujuan untuk menemukan gambaran nasionalisme dalam Al-Quran yaitu dengan cara melacak tema-tema di dalam Al-Quran yang berbicara tentang negeri dan bangsa untuk kemudian melihat bagaimana isyarat kecintaan yang ditujukan oleh penduduknya yang ditujukan bagi negeri atau bangsanya. Ada beberapa kata kunci di dalam Al-Quran yang memiliki makna negeri untuk kemudian dapat ditelaah dalam rangka mengetahui gambaran nasionalisme, yaitu kata su'ūb, bilād dan ummah. Penulis membatasi satu istilah kata kunci nasionalisme di atas dengan satu ayat Al-Quran, untuk kemudian melihat bagaimana hakikat nasionalisme dalam sebuah negara dan bangsa perpektif Al-Quran. Berikut penjelasannya:

\section{1) $S y u$ 'üb}

Kata syu'ūb merupakan kata benda bentuk jama' dari kata tunggal sya'aba (شعب), yasy'abu (يشعب), sya'bun (شعب), yang memiliki arti berpisah, bersatu, merusak, atau memperbaiki.(35) Dalam makna terminologinya, kata syu'ūb bermakna kelompok manusia. Sebagaimana disinggung oleh Sayyid Qutb, yaitu:

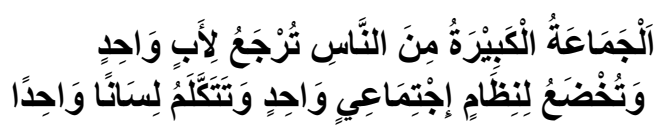

Artinya: kelompok besar manusia yang berasal dari satu bapak, mematuhi aturan sosial yang berlaku, dan berbicara dalam satu bahasa.(9)

Selain penjelasan di atas, al-Marāghī juga menyebutkan bahwa sya'b berarti kelompok besar manusia yang berasal dari satu asal usul, memiliki negeri khusus, dan menampung berbagai kabilah yang lebih umum darinya.(5)

Dari penjelasan di atas, hemat penulis, kata شعوبا dimaknai sebagai kelompok manusia yang menempati satu tempat, berasal dari asal-usul yang sama, dan di dalamnya pun terdiri atas beberapa kelompok-kelompok lainnya. Kaitannya dengan nasionalisme, sekiranya tema ini cocok disandingkan, karena dalam nasionalisme, penduduk yang ada dalam suatu negara-bangsa merupakan kelompok orang yang berasal dari satu tempat dan asal-muasal.

Adapun ayat al-Quran yang mencakupi terma syu'ūb yaitu pada QS. Al-Ḥjurāt [49]: 13:

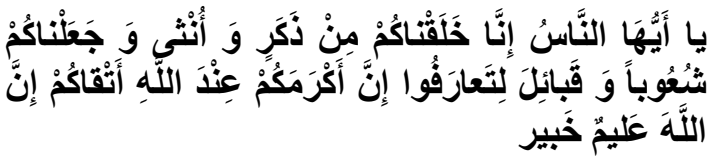

Artinya: Hai manusia, sesungguhnya Kami menciptakan kamu dari seorang laki-laki dan seorang perempuan dan menjadikan kamu berbangsa-bangsa dan bersuku-suku supaya kamu saling kenal-mengenal. Sesungguhnya orang yang paling mulia diantara kamu disisi Alla ialah orang yang paling taqwa diantara kamu. Sesungguhnya Allah Maha Mengetahui lagi Maha Mengenal.

Al-Baiḍāwi dalam tafsirnya menjelaskan ayat di atas, yang isinya bahwa Allah telah menjadikan manusia berbeda-beda, yaitu dari asal kelahiran (ayah dan ibu) yang berbedabeda. Selain itu, manusia juga telah diciptakan dalam bengsa-bangsa dengan maksud agar bisa saling mengenal. Menurutnya, kehidupan berbangsa tidak sedikitpun benar jika ditujukan untuk menyombongkan asal keturunan atau asal bangsanya. Karena sejatinya yang mulia di sisi Allah bukanlah dari bangsa-bangsa tertentu yang ada di manapun, namun mereka adalah orang-orang yang bertakwa dan berakhlak mulia.(4)

Sekiranya jelas apa yang ingin dikatakan al-Baị̣āwī dalam tafsirnya, bahwa manusia diciptakan berbeda-beda dan berbangsabangsa karena tujuan untuk saling mengenal satu sama lainnya. Hal ini men-counter pendapat-pendapat bahwa dalam nasionalisme yang banyak diartikan sebagai paham yang chauvinistic, yang memiliki kecenderungan sombong kepada bangsabangsa lain.

Sementara al-Alūsī menjelaskan ayat di atas, bahwa manusia telah diciptakan dari bapak dan ibu yang sama, dan kemudian menjadi berbangsa-bangsa dan berkelompok- 
kelompok. Semua manusia diciptakan dari keturunan yang sama agar tidak boleh berperilaku sombong antar satu dengan yang lainnya.(2) Diciptakannya manusia dalam berbangsa-bangsa bukan untuk bersaing dengan merendahkan satu sama lain, akan tetapi untuk saling mengenal sehingga dapat meningkatkan ketakwaan dan pengabdian kepada Allah Swt.

\section{2) Bilād}

Kata bilād merupakan bentuk jama' dari kata balad, sebagaimana kata kilāb yang merupakan bentuk jama' dari kata kalbah.(35) Maka, atas dasar ini, secara terminologi, tema bilād memiliki makna yang sepadan dengan kata balad, yaitu tempat yang dihuni oleh sekelompok orang dan dinamakan pula suatu tempat yang luas yang ada di bumi.(40) Dalam hal demikian, tergolong pada bilād adalah negara-negara yang menerapkan sistem nasionalisme, karena di dalamnya hidup sekelompok orang.

Ayat al-Quran yang di dalamnya didapati kata bilād, yaitu pada QS. Al-Fajr [89]: 8:

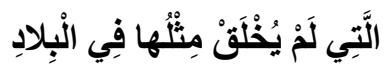

Artinya:..yang belum pernah dibangun (suatu kota) seperti itu, di negeri-negeri lain.

Ayat ini merupakan penjelasan tentang kota Iram, ibu kota dari Kaum 'Ad, yang di dalamnya didapati gedung-gedung yang tinggi dan megah. Gedung-gedung tersebut tidak pernah ada sebelumnya di tempat manapun selain di kota Iram. Kota Iram adalah kota yang di-setting dengan indah di padang 'Ad, selama 300 Tahun. Dalam kota tersebut rumah-rumah dibangun dengan emas dan permata, dan juga didapati berbagai tumbuhan dan tanaman yang bermacammacam.(2)

Dalam tafsir Al-Mishbah, dijelaskan bahwa, ayat ini memberi penegasan agar Nabi Muhammad Saw dan semua umat muslim merenungkan tentang kaum 'Ad, kaumnya Nabi Hud As, yang mendiami kota Aḥqāf, Yaman. Mereka terkenal sebagai bangsa yang kuat, tinggi, besar dan perkas. Hal itu dibutkikan dengan kemampuan mereka membangun kota Iram yang didapati di dalamnya gedung-gedung kokoh dan menjulang tinggi. Mereka juga menguasai bangsa-bangsa lainnya. Namun, akibat pembangkangan yang dilakukannya kepada Allah Swt, mereka dan negerinya dihancurkan oleh-Nya.(35)

Sementara itu menururt al-Buruswī, kota Iram merupakan kota yang megah. Orangorang yang ada di dalamnya memiliki tubuh yang kekar, kuat dan tingginya mencapai 4 dhira'. Dikatakan juga bahwa, orang-orang yang kuat itulah yang membangun bangunanbangunan besar dan megah yang ada di dalamnya. Akan tetapi kaum 'Ad, sebagai pemilik kota Iram dihancurkan oleh Allah sebab sikap sombongnya, yaitu tidak mau beriman dan mengikuti aturan yang Allah tetapkan.(5) Artinya, sekuat apapun kondisi suatu bangsa, manakala Allah tidak meridhoinya dikarenakan perilaku-perilaku yang tidak sesuai aturan yang Allah tetapkan, maka akan tetap hancur dan binasa.

\section{3) Ummah}

Secara etimologi, kata ummah merupakan bentuk mașdār dari fi'il māḍi, yaitu ammayauтmи-ummatan, yang memiliki makna rakyat, umat, atau bangsa. Kata ummah berakar dari amта-yauтmи-ummatan. Sementara itu secara terminologi kata ummah memiliki beberapa arti, yaitu pertama, suatu golongan manusia. Kedua, setiap golongan manusia yang dinisbatkan kepada seorang Nabi tertentu, misalnya umat Nabi Muhammad Saw, dan selainnya. Ketiga, setiap generasi yang menjadi umat yang satu.(35)

As-Șibāghi juga mendefinisikan kata ummah secara terminologi, yaitu sekelompok manusia yang mayoritas berasal dari satu keturunan, memiliki watak yang diwariskan dari pendahulunya, memiliki cita-cita yang sama, atau sekelompok manusia yang terkumpul menjadi satu karena agama, tempat, ataupun masa.(40)

Dari definisi-definisi di atas dapat disimpulkan bahwa ummah atau umat (dalam bahasa Indonesia) ialah sekelompok manusia yang berkumpul menjadi satu karena memiliki cita-cita tertentu, baik masalah agama, tempat tinggal, atau masa yang sama. Maka dalam hal ini bangsa Indonesia juga tergolong ummah.

Adapun ayat al-Quran tentang ummah, yaitu dalam QS. Al-Baqarah [2]: 143: 


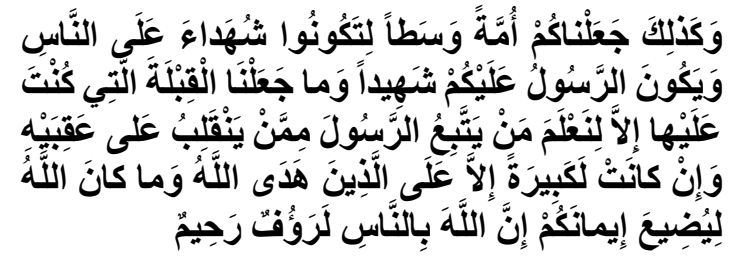

Artinya: Dan demikian (pula) Kami telah menjadikan kamu (umat Islam), umat yang adil dan pilihan agar kamu menjadi saksi atas (perbuatan) manusia dan agar Rasul (Muhammad) menjadi saksi atas (perbuatan) kamu. Dan Kami tidak menetapkan kiblat yang menjadi kiblatmu (sekarang) melainkan agar Kami mengetahui (supaya nyata) siapa yang mengikuti Rasul dan siapa yang membelot. Dan sungguh (pemindahan kiblat) itu terasa amat berat, kecuali bagi orangorang yang telah diberi petunjuk oleh Allah; dan Allah tidak akan menyia-nyiakan imanmu. Sesungguhnya Allah Maha Pengasih lagi Maha Penyayang kepada manusia.

Menurut Quraish Shihab, ayat di atas memberi maksud suatu keharusan bahwa umat Islam sudah semeskinya berlaku moderat. Menurutnya, yang dimaksud moderat dalam ayat ini ialah sikap manusia yang tidak memihak ke kiri dan tidak ke kanan. Sikap demikian merupakan sikap yang mengantarkan mansusia untuk berlaku adil. Posisi umat wasatan juga menjadikan seseorang dapat diterima oleh seluruh kalangan walau berbeda-beda, bahkan orang yang demikaian akan menjadi panutan dan teladan bagi seluruh umat.(35)

Sementara itu menururt Hamka, moderat dalam ayat tersebut mencakup moderat dalam beberapa hal, yaitu moderat dalam berfikir, bertindak, emosional, manajemen pemerintahan, relasi, tempat dan waktu.(9) Sikap moderat menjadi penting bagi sebuah bangsa untuk menciptakan perdamaian dalam sebuah bangsa yang di dalamnya didapati keberagaman.

\section{Metode Penelitian}

Metode yang digunakan dalam tulisan ini adalah metode tafsir tematik, yaitu mengumpulkan tema-tema kunci nasionalisme yang ada dalam al-Quran, yaitu syu'ūb (QS. Al-Hujurāt [49]: 13) yang bermakna bangsa, bilād (QS. Al-Fajr [89]: 8) yang bermakna negeri, dan ummah (QS. AlBaqarah [2]: 143) yang juga bermakna bangsa. Ketiga ayat tersebut dilacak melalui beberapa pandangan Mufasir dengan pendekatan teks dan kontekstual untuk menemukan gambaran nasioanlisme perspektif Al-Quran. Hasilnya dijadikan sebagai kacamata untuk menelaah nasionalisme bangsa Indonesia. Apakah nasionalisme bangsa Indonesia selaras dengan nasionalisme Al-Quran atau tidak, dan juga apakah nasionalisme Indonesia juga tergolong chauvinisme dan xenhopobia, atau bukan sama sekali.

\section{Hasil dan Diskusi \\ a. Nasionalisme Qurani: Semangat Kebangsaan}

Secara tersirat, di atas telah dipaparkan bahwa, nasionalisme yang berkembang di dunia saat ini terbagi atas dua bentuk, yaitu nasionalisme dalam makna luas dan nasionalisme dalam makna yang sempit. Nasionalisme dalam makna luas ialah sikap cinta dan membanggakan bangsa dan negerinya sendiri dan tidak menganggap rendah bangsa-bangsa yang lain. Sebaliknya, nasionalisme dalam makna sempit ialah nasionalisme yang mengunggulkan bangsanya sendiri dan merendahkan bangsa lain, bahkan berambisi untuk menjajah bangsa-bangsa di luar bangsa dirinya. Nasionalisme dalam makna luas, dalam istilah lain juga diistilahkan dengan semangat kebangsaan. Sedangkan yang bermakna sempit diistilahkan juga sebagai nasionalisme ideologis yang sangat fanatik terhadap bangsa atau negeri sendirinya, dan merendahkan bangsa lain, bahkan identik mendahulukan kecintaan kepada bangsa daripada kecintaan pada agama.(24)

Sejauh penelaahan penelitian ini, nasionalisme yang ditegaskan dalam AlQuran ialah nasionalisme dalam makna luas atau semangat kebangsaan. Kenyataan tersebut dapat dibuktikan dengan beberapa ayat Al-Quran di atas yang memberi isyarat yang kuat akan sikap mencintai dan mengunggulkan negeri dan bangsanya sendiri namun tidak merendahkan negeri atau bangsa lain, seperti yang terdapat pada penjelasan tentang kehebatan dan keistimewaan bangsa kota Iram (Ibu kota kaum 'Ad) karena memiliki gedung-gedung yang menjulang tinggi; tubuh penduduknya yang kekar-kekar, kuat dan tinggi; dan di dalamnya di dapati 
gedung-gedung yang terbuat dari emas serta permata, yaitu pada penjelasan QS. Al-Fajr [89]: 8. Hal yang perlu digaris bawahi, ketika para Mufasir menjelaskan ayat ini dengan sangat jelas memaparkan tentang keistimewaan dan kemegahan kota Iram, besarnya kekuatan yang dimiliki penduduknya, dan keistimewaankeistimewaan kota Iram lainnya. Dalam penjelasannya itu, tidak ada indikasi sedikitpun yang dilakukan oleh kaum 'Ad, berupa sikap merendahkan negeri atau bangsa di luar kota Iran. Kenyataan ini semakin membuktikan bahwa nasionalisme di dalam Al-Quran ialah nasionalisme dalam makna luas yang tidak memiliki sikap sombong kepada bangsa lain.

Kenyataan bahwa hakikat dan makna nasionalisme di dalam Al-Quran adalah nasionalisme yang bermakna luas (semangat kebangsaan) juga didukung oleh ayat AlQuran yang lain yang menyatakan bahwa Allah Swt menciptakan manusia berbangsabangsa bukan untuk saling bermusuhan, membenci dan merendahkan satu sama lain. Akan tetapi guna saling mengenal sehingga dapat meningkatkan ketakwaan, yaitu pada QS. Al-Hujurāt [49]: 13. Selain itu, di dalam nasionalisme, umat juga dituntut untuk bersikap moderat, sebagaimana pada penjelasan QS. Al-Baqarah [2]: 143 di atas.

Dengan pernyataan bahwa nasionalisme yang dikehendaki Al-Quran ialah nasionalisme dalam makna luas, juga memberi kesimpulan keselanjutnya bahwa diciptakannya manusia dalam bentuk bangsabangsa, bukan berarti umat Islam akan terpecah belah setelah dipisahkan oleh teritorial wilayah. Karena pada QS. AlHujurāt [49]: 13 tersebut secara jelas ditegaskan bahwa manusia (termasuk umat Islam) diciptakan dengan berbangsa-bangsa supaya satu dengan yang lain saling mengenal. Ungkapan "saling mengenal" ini, hemat penulis, memberi ruang yang sangat besar bahwa persatuan umat Islam masih bisa terjaga walaupun antar satu umat Islam dengan umat Islam yang lain telah dibatasbatasi dalam wilayah tertentu. Batas-batas wilayah tidak serta merta memastikan semangat persatuan umat Islam. Pernyataan ini menjawab asumsi yang menyatakan bahwa nasionalisme akan memecah belah umat Islam.
Akhirnya dalam sub bab ini penulis menyimpulkan, bahwa nasionalisme yang dikehendaki Al-Quran ialah nasionalisme yang memiliki makna luas atau semangat kebangsaan. Nasionalisme dalam Al-Quran tidak bersifat chauvinistic atau xenophobia; yaitu nasionalisme yang membanggakan negeri atau bangsa sendiri dan merendahkan bangsa-bangsa yang lain. Fakta nasionalisme Al-Quran yang bermakna luas itu juga memberi kesimpulan yang dibawahnya, yaitu bahwa dengan diciptakannya manusia dalam batas wilayah-wilayah tertentu, persatuan umat Islam masih tetap bisa untuk dijaga.

\section{b. Nasionalisme Perspektif Al-Quran dan Kebangsaan Indonesia}

Di dalam bab sebelumnya secara jelas ditegaskaan bahwa nasionalisme bangsa Indonesia muncul karena semangat melawan kolonialisme. Nasionalisme Indonesia terbangun karena kehendak yang cukup kuat dari penduduknya untuk bersatu melawan penjajahan yang terjadi selama ratusan tahun. Bukan hanya itu, persatuan yang lahir dalam rangka melawan penindasan penjajah itu pun setelah berhasil tidak berhenti sampai di situ, melainkan memiliki cita-cita luhur untuk membangun sebuah tatanan bangsa dan masyarakat yang adil dan sejahtera.(31) Hemat penulis, dari pernyataan ini, ada tiga poin penting yang menjadi karakter nasionalisme Indonesia, yaitu persatuan, keadilan dan kesejahteraan.

Atas dasar di atas, secara konseptual, nasionalisme Indonesia memiliki kesesuaian (relevansi) dengan nasionalisme yang digagas dalam Al-Quran dengan melihat kecocokkan yang sama antara prinsip nasionalisme di dalam Al-Quran dan tiga karakter nasionalisme Indonesia. Pertama, persatuan Kedua, keadilan; kedua konsep ini selaras dengan makna nasionalisme yang dikandung dalam penjelasan QS. Al-Hujurāt [49]: 13, yaitu tentang keharusan suatu syu' $\bar{u} b$ (bangsa) untuk hidup di dalam suatu tempat (negara) dengan tidak atas dasar kesombongan, agar saling mengenal satu sama lain, dan sadar bahwa diciptakannya adalah murni untuk meningkatkan ketakwaan kepada Allah Swt.

Ketiga, kesejahteraan; kesejahteraan yang menjadi cita-cita kebangsaan Indonesia juga selaras dengan QS. Al-Fajr [89]: 8, dalam 
bahasan terma bilād (suatu negeri), yaitu negeri Iram yang hidup dalam kemewahan dan kemegahan. Warga di dalam negeri Iram menjadi sejahtera merupakan bukti bahwa dalam berbangsa (nasionalisme) perspektif Al-Quran penduduk di dalamnya harus merasakan kesejahteraan dan kecukupan.

Kesejahteraan juga merupakan implikasi dari sikap moderat, sebagaimana dalam penjelasan QS. Al-Baqarah [2]: 143, mengenai terma ummah, bahwa suatu umat (bangsa) hendaknya bersikap moderat. Menurut Qutb dalam penjelasan tafsir ayat di atas, sikap moderat harus teraplikasikan dalam segala hal, termasuk dalam kesejahteraan yang dilakukan oleh pemerintah sebuah bangsa dan negara. Sikap moderat menjadi poin penting untuk menciptakan kesejahteraan yang merata kepada masyarakat sebuah negara-bangsa.

Hemat penulis, ketiga poin di atas merupakan hal penting dalam praktik persatuan dan juga keadilan. Sebab persatuan dan keadilan yang tidak didasari dengan ketidak-sombongan, saling mengenal dan semangat takwa, maka mustahil untuk tercapai dengan sebenar-benarnya persatuan dan keadilan.

Oleh hal ini hemat penulis, nasionalisme yang dimiliki oleh bangsa Indonesia, hakikatnya, bukanlah nasionalisme yang berbau chauvinistic dan xenophpbia, yang nihil akan persatuan, keadilan dan kesejahteraan yang hakiki. Nasionalisme demikian hanya berujung membanggabanggakan negeri sendiri dan merendahkan bangsa-bangsa lain, bahkan menjajahnya. Sementara nasionalisme Indonesia yang merupakan semangat kebangsaan yang diprakarsai atas perlawanan kepada para penjajah dan para perilaku perampasan hak asasi kemanusiaan di Indonesia sarat akan persatuan, kedailan dan cita-cita kesejahteraan. Nasionalisme Indonesia relevan dengan nasionalisme yang digagas di dalam al-Quran dalam bahasan ayat-ayat yang terkandung terma syu'ūb, bilād dan ummah.

\section{Kesimpulan}

Nasionalisme di dalam Al-Quran ialah nasionalisme dalam makna luas, yaitu nasionalisme yang membanggakan negeri dan bangsa, tanpa merendahkan negeri atau bangsa yang lain. Atau dalam istilah lain, nasionalisme di dalam Al-Quran yaitu semangat kebangsaan. Kesimpulan ini juga memberikan gambaran bahwa nasionalisme tidak akan memecah belah persatuan umat Islam. Karena nasionalisme dalam makna luas memiliki ruang untuk saling mengenal antar satu bangsa dengan bangsa lain, tidak terkecuali untuk muwujudkan persatuan umat Islam. Selanjutnya, secara konseptual, nasionalisme dalam Al-Quran dengan nasionalisme Indonesia memiliki relevansi, yaitu dengan melihat tiga kesamaan prinsipprinsipnya, yaitu persatuan, keadilan dan kesejahteraan.

\section{References}

1. Aidit. Membela Pancasila. Jakarta: Pembaruan, 1964.

2. Al-Alūsī AM. Rūh al-Ma'ānī. Beirut: Dār al-Kitāb al-'ilmiyyah, 1415.

3. Alan WT. Demi Bangsaku: Pertentangan Bung Karno vs Bunng Hatta. Jakarta: Gramedia, 2003.

4. Al-Baị̣āwī A ibn 'Umar. Anwār atTanzīl wa așrār at'ta'wīl. Beirut: Dār Ihyā at-Turāth al-'Arabī, 1418.

5. Al-Buruswī I Ḥaqqī. Tafsir Rūh alBayān. Beirut: Dār al-Fikr, [date unknown].

6. Ali AU. Nasionalisme dan Perjalanan Demokrasi. UNISIA 0: 318-330, 2016.

7. Arifin M. Quran \& Answer: 101 Soal Keagamaan Sehari-hari. Jakarta: Lentera Hati, 2013.

8. Aritonang J. Sejarah Perjumpaan Kristen dan Islam di Indonesia. Jakarta: BPK Gunung Mulia, 2004.

9. As-Syādhilī A-SQII. Tafsir F̄̄ zilāal alQur'ān. Beirut: Dār al-Syurūq, 1412.

10. Azis A. Chiefdom Madinah. Jakarta: Alvabet, 2016.

11. Azra A. Transformasi Politik Islam. Jakarta: Prenadamedia Grup, 2016. 
12. Bawazir T. Jalan Tengah Demokrasi. Jakarta: Pustaka Al-Kautsar, 2015.

13. Dian S, Dr. TSSA. Konsep Nasionalisme Menurut Sayyid Muhammad dalam kitab al- Taḥliyyah wa al- Targhīb fì al- Tarbiyyah wa alTahz̄īb dan Implikasinya pada Pengembangan Karakter Cinta Tanah Air [Online]. IAIN SURAKARTA: $2017 . \quad \mathrm{http} / / /$ eprints.iainsurakarta.ac.id/565/ [21 May 2019].

14. Dwiyanto A. Mengembalikan Kepercayaan Publik Melalui Reformasi Birokrasi. Jakarta: Gramedia, 2011.

15. Grosby S. Sejarah Nasionalisme: Asal Usul Bangsa dan Tanah Air. Terj. Teguh Wahyu. Yogyakarta: Pustaka Pelajar, 2011.

16. Gunawan R. Muhammad Yamin dan Cita-Cita Persatuan Indonesia. Yogyakarta: Ombak, 2005.

17. Halliday F. The Globalization of World Politics. Oxford: Oxford University, 1997.

18. Hamid ES. Peran Pembangunan Untuk Mengukuhkan Nasionalisme Dan Membangun Karakter Bangsa. Jurnal Fakultas Hukum UII XXXIV: 41-46, 2012.

19. Hartono C, Ukur F, Mulder DC. Konteks berteologi di Indonesia: buku penghormatan untuk HUT ke-70 Prof. Dr. P.D. Latuihamallo. BPK Gunung Mulia, 1988.

20. Hawi A. Muhammad Iqbal dan Ide-Ide Pemikiran Politiknya. MADANIA: JURNAL KAJIAN KEISLAMAN 20: 241-250, 2016.

21. Hidayat K. Islam dan Keindonesiaan. Bandung: Mizan, 2014.

22. Khadijah K. Wacana Nasionalisme Dalam Novel Penakluk Badai Karya Aguk Irawan Mn. Jurnal Studi Agama dan Masyarakat 12: 35-56, 2016.
23. Kohn H. The Idea of Nationalisme. New York: Macmillan, 1994.

24. Madjid N. Khazanah Intelektual Islam. Jakarta: Bulan Bintang, 1984.

25. Moesa AM. Nasionalisme Kiyai. Yogyakarta: Lkis, 2007.

26. Murod M. Doa Andalan Para Nabi. Jakarta: Zaman, 2008.

27. Mustaqim A. Metode Penelitian AlQuran dan Tafsir. Jakarta: Idea, 2015.

28. Natsir M. Agama dan Negara dalam Perspektif Islam. Jakarta: Media Dakwah, 2001.

29. Notosusanto P. Sejarah Nasionalisme Indonesia. Jakarta: Balai Pustaka, 1993.

30. Pamungkas C, Hisyam M. Indonesia, Globalisasi, dan Global Village. Jakarta: Yayasan Pustaka Obor, [date unknown].

31. Pureklolon T. Sejarah Demokrasi Indonesia. Jakarta: Gramedia, 2016.

32. Purwanto B, Adam AW. Menggugat historiografi Indonesia. Ombak, 2005.

33. Rahmat MI. Arus Baru Islam Radikal. Jakarta: Erlangga, 2007.

34. Renan E. U'est-Ce Qu'une Nation (What Is Nation?). Terj. MartinIhom. New York: Routledge, 1990.

35. Shihab MQ. Tafsir Al-Mishbah: Pesan, Kesan dan Keserasian Al-Quran. Ciputat: Lentera Hati, 2002.

36. Smith A. Nasionalisme: Teologi, Ideologi, Sejarah. Terj. Frans Kowa. Jakarta: Erlangga, 2003.

37. Sucipto H. Ensiklopedia Tokoh Islam dari Abu Bakar hingga Nasr dan Qardhawi. Jakarta: Hikmah, 2003.

38. Suhelmi A. Pemikiran Politik Barat. Jakarta: Gramedia, 2001. 
39. Yatim B. Soekarno, Islam dan Nasionalisme. Bandung: Nuansa, 2001.

40. at-Wațaniyyah fì Naẓri al-Islām [Online]. www.alukah.net: 2:55:00 PM. http://www.alukah.net/sharia/0/66208/ [20 May 2019]. 